\title{
Oral Histories of the Stolen Generation
}

\section{Sonia Smallacombe}

Aboriginal and Torres Strait Islander cultures were, and continue to be, transmitted through the oral tradition. Oral knowledge was, and continues to be, transmitted face to face, person to person through story telling and drama. It has only been in the past two hundred years in this country that written culture has dominated the way in which knowledge is passed on. The Australian colonisers have relied on written sources and most written sources give the view of the past 'from above', that is, from the view of the powerful. ${ }^{1}$ Therefore, written sources do not give the views of people who are not in positions of power such as the Aboriginal and Torres Strait Islander peoples.

The fact that Aboriginal and Torres Strait Islander viewpoints are largely excluded from this country's history, motivated me to commence a project involving the recording of oral histories of Aboriginal people in the Northern Territory who were removed as children from their parents in the 1940s, 1950 and 1960 and placed in a Catholic Mission called Garden Point on Melville Island. This particular mission has significance for me personally as my mother, who passed away in 1982, was also placed at Garden Point. This mission no longer exists as the Catholic Church's lease on Garden Point expired in the 1970s. Under the Aboriginal Land Rights (NT) Act 1976, the land was returned to the original owners - the Tiwi people - and the mission reverted to its original Tiwi name, Pularumpi. ${ }^{2}$

The abduction of Aboriginal children from their families took place throughout Australia as part of the aggressive assimilationist policies that were implemented by state and 
federal governments from the nineteenth century until the 1970s. Almost every Aboriginal person in this country has been affected in some way; either they had relatives placed in institutions or they themselves were removed from their families. These people were wrenched from their families and their traditional lands as children and small babies and spent most of their childhood and often some of their adulthood in church and government institutions. Through no fault of their own, these people were cut off from the lands of their ancestors for the purpose of assimilation into white society, a society that had no intention of accepting them.

As an Indigenous researcher, I realised my work was addressing very sensitive issues and therefore it was essential that my research practices adhered to the protocol and etiquette that already existed in the community. This involved negotiating the research project so that it would be of benefit to the people themselves. It was important that the people volunteered to participate in the project, to shape the stories in the way that was comfortable for them and to feel a sense of ownership of the project. Consultation, negotiation and ownership of research projects involving Indigenous peoples have always been major issues. Aboriginal and Torres Strait Islander people have become highly critical and cynical of research practices that are intrusive, exploitative and of no real value to our communities. There is a growing interest in self-empowerment among Indigenous peoples in regard to research conducted in our communities about our cultures and people. ${ }^{3}$

As an Indigenous researcher I was aware that a form of continuum exists in oral stories and, therefore, the stories may not have a 'beginning' or an 'end' to them. I was faced with the dilemma of having to introduce a 'beginning' to the stories and made the decision to begin with the question: 'What do you remember of being taken from your family?' This enabled the participant to frame their response in a way that was suitable and comfortable for them. For example, they might begin to describe what they remember of being taken by police or welfare officers from their families, or comment that they were too young to remember as many were small babies removed from their mother either at, or soon after their birth. Others 
would have no memory of that traumatic day - therefore their memories had been repressed.

The stories could take any direction from this 'starting point'. For example, the people would talk about growing up on the mission or, depending on their age, would have memories of living with their families before being taken to the mission. Many remember the boat trip to Garden Point, of the rough seas, of being violently ill and huddling on the deck and crying because they were scared and being comforted by the Aboriginal crewmen - not the missionaries who were also on the boat. However, the stories were continually framed around thoughts of home, about their families, especially their mother. They also included relationships formed with other children on the mission who were incorporated as part of their family. For many, being with other children on the mission was the only family life they experienced.

The issue of inserting a 'beginning' and 'ending' to the oral narrative left me wondering whether it would have been better to let the participant begin their own story. The attachment to land and kinship ties are significant to Aboriginal and Torres Strait Islander peoples, especially for those Stolen Generation people who have been able to find out about their kin and country. This is often demonstrated when Aboriginal and Torres Strait Islander people meet each other for the first time. They will often ask 'Where are you from?' or 'Who are your mob/people?' Therefore, most people begin their stories or introduction by talking about their kin and their ancestral lands. They often describe how they came to be a part of the land through their ancestors - for example, great, great grandmothers or great, great grandfathers. Although they may not have personally met this person, they know about them through the stories that have been handed down through the generations. Likewise, where does the story end? In the research project, the stories would end when the tape in the cassette recorder ran out. Therefore, the stories would seem to be incomplete, however, it does provide the opportunity for the participants to add to the stories if they wish to do so. Also, the stories did not end when the participant left the mission. It seemed important for the participants to talk about their survival and the way in which they continue to grapple with 
the despair, heartaches and pains that has become a constant reminder of their past.

Recording Aboriginal oral histories has the advantage of providing an important insight into cultural forms of knowledge. The stories are not necessarily shaped by western forms of linear historical 'progression'. The Working Party of Aboriginal Historians formed for the Bicentennial History in the early 1980 s point out in their article titled 'Preparing Black History' that Aboriginal chronology takes many forms, particularly a cyclical or spiralling one that locates certain periods according to the seasons. ${ }^{4}$ These aspects were evident in the stories told to me. They talked about the seasons when referring to times of the year such as the 'dry season' or the 'wet season'. In respect of dates, many of the Stolen Generation were given birth dates by the missionaries and it appears that these dates were based on the appearance of the physical features of the child-for example, the child looked eight years old or fifteen years old. Therefore, when describing an event the participant would say 'My sister Mary was the baby, so I must have been six years old as there is are six years difference between me and Mary'.

As an Indigenous researcher I am aware of the need to communicate the work of the project and its outcomes in language that is accessible to community members. Too often research reports are written about us in a language that appeals only to a small, (western) educated elite group. Indigenous researchers are critical of research that is controlled by European language, structures and concepts which inevitably distort the truths of Indigenous peoples. Also, for far too long, Indigenous peoples have not had the power to choose what is being said, how it is to be expressed and how our words should be written. ${ }^{5}$ It is for these reasons that the oral histories were recorded in the speaker's language. It was felt that to translate the words of the people into 'academic' English would not only be an injustice to the people but the interviews would lose their meaning.

During my undergraduate years at university, I was often involved in heated debates with my lecturers over the issue of using documentary records versus oral histories. From my experience, many white academics make the claim that oral 
narratives are subjective and therefore are considered to be an unreliable source, while the use of documentary records are considered to be objective and, therefore, reliable. I believe one only has to read the newspaper to refute this argument. Another argument is that oral narratives are based on selective memory and is therefore limited in producing the full record of events. I would argue that most written sources do not produce the full record of events.

An example of the limitations of documentary records is outlined in Telling It Like It Is (1992) by Penny Taylor where an Aboriginal historian, Paul Brehrendt, went through every copy of a local newspaper printed in a New South Wales town over a three-year period in the 1930s. He wrote in 1986: 'The only mention of the Aboriginal population was in the police and court reports. There were no references to any achievements, any opinions, or indeed any complaints' (34). For this reason, he did extensive interviews in the same area and found out that Aboriginal people were the unsung backbone of the rural industry. There was hardly a property that did not employ Aboriginal workers on either a casual or permanent basis at that time. Yet, the written records failed to acknowledge the economic contribution of Aboriginal people in the area (35).

The recording of the stories of Aboriginal people who were removed from their families as children was a difficult and traumatic process as they re-lived their experiences. To their credit, many people agreed to tell their stories because they believed it to be an important record of their lives that can be passed on to their children and grandchildren. They also believed that it is important that the Australian population know about the experiences of Aboriginal people.

Writing and recording oral histories does not replace storytelling. Aboriginal and Torres Strait Islander people continue to tell stories around the campfire, at home or at community functions. Some Aboriginal and Torres Strait Islander people prefer to keep stories in the oral tradition and therefore, do not wish to write them down. The stories remain the property of Aboriginal and Torres Strait Islander people and it stays close to the old ways of passing on knowledge (14). Oral histories can be used to emphasise self-empowerment as it enables Aboriginal and Torres Strait Islander peoples to 
tell their stories in their own voice. This has been extremely important for the members of the Stolen Generation who were prevented by missionaries and government policies from openly maintaining and passing on their cultural heritage. In reclaiming Indigenous history and Indigenous culture and taking responsibility for passing it on to future generations, oral narratives are also part of the political struggle.

\section{Notes}

1 Penny Taylor, Telling It Like It Is, Australian Institute of Aboriginal and Torres Strait Islander Studies, Canberra, 1992, p. 34. Further references will be included within the text. Br. John Pye, 'Early Days at the Mission at Garden Point' in Thecla Brogan (ed.), The Garden Point Mob, Historical Society of the Northern Territory, Darwin, 1990, p. 1 .

3 Anne-Marie Tupuola, 'Is There Room for Non-exploitative Methodology in the Academic World'? (Paper presented at the World Indigenous People's Education Conference, Wollongong, 11-17 December 1993),

4 p. 12.

5 'Preparing Black History' by The Working Party of Aboriginal Historians for the Bicentennial History 1788-1988 in Marji Hill and Alex Barlow, Black Australia 2, Aboriginal Studies Press, Canberra, 1985, pp. 7-8. 